Western North American Naturalist 67(3), ㄷ 2007, pp. 384-388

\title{
BLACK BEARS (URSUS AMERICANUS) HARVEST JEFFREY PINE (PINUS JEFFREYI) SEEDS FROM TREE CANOPIES
}

\author{
Kellie M. Kuhn ${ }^{1,2}$ and Stephen B. Vander Wall ${ }^{1}$
}

\begin{abstract}
We documented black bears (Ursus americanus) consuming the seeds of Jeffery pine (Pinus jeffreyi) in the eastern Sierra Nevada from late August through September. Shells of pine seeds were the exclusive item in 20 of 27 scat samples collected in September and October and comprised $>90 \%$ of the remaining 7 samples. Bears obtain seeds of Jeffrey pines by climbing trees, removing ripe, unopened cones from branches, dismantling cones on the ground, and consuming the seeds. Cone harvesting by bears can cause substantial damage to cone-bearing trees and might result in high predispersal mortality of seeds. In other regions, the use of pine seeds by bears has been associated with whitebark pines (P. albicaulis) from which bears obtain seeds by exploiting the cone-storing activities of squirrels. Despite the lack of an apparent pine-squirrel-bear interaction, harvesting unopened cones might be a common foraging strategy used by black bears to obtain seeds of Jeffrey pines in the Sierra Nevada.
\end{abstract}

Key words: black bear, cone harvesting, diet, Jeffrey pine, Pinus jeffreyi, seed predation, Tamiasciurus, Ursus americanus.

Black bears (Ursus americanus) are large, generalist omnivores that consume a broad range of foods. In some regions, pine seeds make up a large proportion of the autumn diet of black bears (Tisch 1961). Pine seeds are nutritious (rich in fat and protein with a high caloric content), highly digestible (Mealey 1975), and seasonally abundant. However, pine crops are ephemeral and are not a dependable food supply (i.e., cone crops are small in some years; Forcella 1978). In western North America, black bears and brown bears (U. arctos) shift foraging habits to correspond to availability of pine seeds (Kendall 1983, Craighead et al. 1995, Beckmann and Berger 2003a). When pine seeds are available, bears eat them almost to the exclusion of other foods (Kendall 1983, Craighead et al. 1995).

In western Nevada, black bears prefer coniferous forests over open shrubland habitats (Goodrich 1990). This preference has been attributed primarily to the presence of cover and not to food resources (Goodrich 1990). However, in addition to cover, Jeffrey pine (Pinus jeffreyi) provides a potentially important food resource for black bears. Seeds of Jeffrey pine ripen and cones open in midAugust to late September. Seeds are available only for a brief period, because when cones open, seeds are dispersed by the wind. Once on the ground, seeds are gathered rapidly and stored by chipmunks (Tamias spp.), mice (Peromyscus spp.), and other rodents (Spermophilus lateralis, S. beecheyi, Tamiasciurus douglasii, and Sciurus griseus; Vander Wall 1994). Here we demonstrate that seeds of Jeffrey pine can compose a large proportion of the autumn diet of black bears in the Sierra Nevada. To our knowledge, no studies have determined how black bears obtain Jeffrey pine seeds. Though it has been well documented that black bears will climb trees to obtain food (e.g., Schaller et al. 1989, Pelton 2003), harvesting of pine cones by bears usually has been closely tied to exploitation of red squirrel (Tamiasciurus hudsonicus) middens (Kendall 1983, Craighead et al. 1995, McCutchen 1996, Mattson and Reinhart 1997, Mattson et al. 2001). Here we describe a behavior in which black bears climb Jeffrey pine trees, break cone-bearing branches, dismantle the ripe, unopened cones, and consume the seeds.

\section{Methods}

We conducted this study in the Whittell Forest and Wildlife Areas, Little Valley, Washoe County, Nevada. Whittell Forest is located in the Carson Range $\sim 30 \mathrm{~km}$ south of Reno, Nevada $\left(39^{\circ} 15^{\prime} 10^{\prime \prime} \mathrm{N}, 119^{\circ} 52^{\prime} 35^{\prime \prime} \mathrm{W}\right)$, at an

${ }^{1}$ Department of Biology and the program in Ecology, Evolution, and Conservation Biology, University of Nevada, Reno, NV 89557.

2E-mail: kuhnk@unr.nevada.edu 
elevation of 1960-2680 m. The density of bears in the area is $\sim 3.2$ individuals $\cdot 100 \mathrm{~km}^{-2}$ (Beckmann and Berger 2003b). The dominant tree species are Jeffrey pine (P. jeffreyi) and lodgepole pine $(P$. contorta), and dominant understory shrubs include antelope bitterbrush (Purshia tridentata), tobacco bush (Ceanothus velutinus), greenleaf manzanita (Arctostaphylos patula), and Sierra chinquapin (Castanopsis sempervirens). At this site, seeds of Jeffrey pines are eaten and dispersed by deer mice (Peromyscus maniculatus), yellow-pine chipmunks (Tamias amoenus), long-eared chipmunks (T. quadrimaculatus), golden-mantled ground squirrels (Spermophilus lateralis), and California ground squirrels (S. beecheyi). Douglas's squirrels (Tamiasciurus douglasii) cut cones off Jeffrey pines and store them individually in holes in the ground. Birds that eat pine seeds in Whittell Forest include Steller's Jays (Cyanocitta stelleri), Clark's Nutcrackers (Nucifraga columbiana), and Red Crossbills (Loxia curvirostra).

We collected data for this study opportunistically while conducting a study on yellowpine chipmunks. We observed that bears were harvesting cones from the tops of trees during early September 2002 and 2003. In 2002 we identified 18 trees from which bears had harvested cones (hereafter referred to as "bear trees") based on the presence of shredded cones, freshly broken branches beneath trees, and claw marks on tree trunks. Cones dismantled by bears were distinguished easily from those stripped by squirrels; bears shredded cones into small pieces, whereas squirrels obtained seeds by removing pine scales, leaving cone cores intact. For each bear tree, we measured the diameter at breast height, and using a clinometer, we measured height of the lowest limb and total height. Additionally, we measured the diameter of broken branches with cone scars, counted the number of cone scars per branch, and estimated the number of shredded cones beneath bear trees.

We estimated cone production in 2003 by counting all the cones on 29 mature Jeffrey pines. Trees were arbitrarily selected because cones could be counted from all sides. Cones were counted on each tree in August with aid of binoculars and a spotting scope. To determine the number of viable seeds per cone, we collected 51 cones from Jeffrey pines that had low-hanging branches and we allowed these cones to air-dry until open. After cones opened we determined the number of filled (potentially viable) seeds, empty seeds, and insectinfested seeds per cone. These data enabled us to estimate average seed production.

We collected bear scats on 9 September 2002 while walking along an arbitrarily selected 2.7- $\mathrm{km}$ linear transect and along $7 \mathrm{~km}$ of dirt road on 31 October. Twenty-three scats were collected in the forest and 4 were collected from the shrub habitat. In 2 cases, 2 samples were collected from beneath the same bear tree (in both cases 1 scat appeared to be from an adult bear and 1 from a juvenile). Scats were frozen for later analysis. We soaked scat samples in a $2 \%$ bleach solution until soft, teased them apart, and then soaked them for an additional 2 minutes. Samples were washed through a series of 5 sieves to separate solids by size. The smallest sieve (pore size $710 \mu \mathrm{m}$ ) precluded loss of small seed fragments. Samples were rinsed until only undigested food items remained. We pooled the contents of sieves and dried them in an oven at $45^{\circ} \mathrm{C}$. Shells of pine seeds, wings of seeds, and grass were separated and weighed. Other food items were separated, identified, and counted.

To determine the relationship between the mass of shells and the number of seeds eaten, we hulled 200 Jeffrey pine seeds and removed the kernels. We air-dried shells for 28 days, and then weighed them prior to simulating mastication by crushing. We washed the crushed seed shells through the same set of sieves used for scat samples, and then ovendried and reweighed the pooled shell fragments. To estimate the number of pine seeds in scats, we divided the mass of the seed shells that we had separated from the scat by the mass of our 200 crushed and dried seed shells, and then multiplied by 200 .

In addition to dietary analysis, we made opportunistic observations of bears consuming seeds from beneath Jeffrey pines and of bears harvesting cones from the tops of trees in September 2003.

\section{RESUlTS}

In 2002 we located 27 scat samples, which contained shells of $\sim 32,513$ Jeffrey pine seeds. Two scats with small diameters contained an estimated 268 and 379 seed shells, respectively. We estimated that the remaining 25 
scats each contained $\sim 1274 \pm 627$ seeds (range 492-3251 seeds per scat; each mean is reported with 1 standard deviation). We are not sure how many bears produced these scats, but we are fairly certain that the scats were from several different individuals. During this study, we observed 14 bears (some marked with eartags and radio-collars and some unmarked) on the study site. Additionally, we found hair of 3 different shades on the bark of 5 bear trees. Finally, bear trees were often near each other but groups of these trees were sometimes spaced up to $7 \mathrm{~km}$ apart.

We found only 4 unmasticated seeds in 1 scat sample $(0.012 \%$ of estimated consumed seeds). Wings from pine seeds were found in large quantities in scats; in some cases, they approximated the number of estimated seeds. However, little debris from cones was found in scats ( $n=3$ cone scales, all samples combined), indicating that bears were adept at separating seeds from cone material.

Food items other than pine seeds were found in 7 scats. Five scats contained grass $(1.78 \pm 0.93 \mathrm{~g}), 3$ contained wasp fragments (Vespula spp.), and 1 contained part of an undigested chipmunk (Tamias sp.). In addition, 1 scat contained seeds from 67 manzanita fruits, 2 Prunus pits, and 2 rodent claws; however, shells of pine seeds represented $>90 \%$ of the sample.

In 2002 Jeffrey pines produced $92.0 \pm 92.7$ cones per tree $(n=29$ mature trees) containing $90.9 \pm 65.3$ filled seeds per cone $(n=51$ cones). Thus, we estimated that average seed production in 2002 was $\sim 8363$ seeds per tree. On average, 1 scat from an adult bear represented the consumption of all seeds from 14 cones, assuming the bear consumed all the seeds within those cones. We found $22.6 \pm$ 20.3 broken branches (range 1-88) beneath bear trees and $9.4 \pm 17$ cone scars per bear tree. Numbers of shredded cones per tree (27.3 \pm 26.5 , range 4-102) often exceeded the number of cone scars on branches. We estimated that 27 cones represent about $30 \%$ of the cone production of a Jeffrey pine in 2002.

On 13 September 2003, 1 of us (Kuhn) observed a sow and her 2 cubs licking winddispersed pine seeds from off the ground. The 2 cubs ( 7.5 months old) climbed a Jeffrey pine tree and foraged on cones, while the sow continued to lick pine seeds from the ground beneath the tree. Initially, the cubs obtained seeds by licking them from open cones. They also harvested cones by pulling the branches close to themselves with their mouths and then stripping cones from branches with their forepaws. The cubs also jumped up and down on branches, which caused seeds to fall from open cones and also some cones to fall to the ground. Most harvesting behavior was observed while cubs were at the top of the tree $(\sim 24 \mathrm{~m}$ above ground) where cones were closest to the trunk and diameters of branches were small. In 2 instances when cones were not easily stripped from branches, 1 cub twisted a coneladen branch around a larger branch until the cone-laden branch broke. All broken branches with cones were dropped to the ground. At 1 point, the mother ascended the tree (to about $3 \mathrm{~m}$ ) and mouthed an unopened cone. However, she stopped foraging and became vigilant on a large, low limb. Cubs harvested 12 cones before being startled by the observer. When they descended, all 3 bears retreated into the forest and did not feed on the fallen cones.

\section{DISCUSSION}

The results of our study show that (1) black bears consume Jeffrey pine seeds during early to late autumn, (2) seeds of Jeffrey pines were a significant food of black bears in 2002, (3) harvesting of pine seeds by bears can result in substantial damage to cone-bearing trees, and (4) black bears do not disperse the seeds of Jeffrey pine.

We suspect that Jeffrey pine seeds from harvested cones are among the most important dietary items for black bears in the eastern Sierra Nevada during the months when bears prepare for winter dormancy. Twenty of the 27 scat samples collected in 2002 were composed entirely of shell fragments from pine seeds. Seeds of Jeffrey pines are rich in fat $(47.8 \%)$ and protein $(31.5 \%$, based on wet seed mass; Vander Wall 1995). Assuming 1274 seeds per scat and 7 scats per day (range 0-7 scats per day for grizzly bears; Roth 1980), adult bears could consume about 267,540 seeds over 30 days. At $66.5 \mathrm{mg}$ and $1685 \mathrm{~J}$ per seed (Vander Wall 1995), this large number of seeds is equivalent to about $17.8 \mathrm{~kg}$ and $450,805 \mathrm{~kJ}$.

We suggest that 2 factors contribute to differences in foraging behaviors of black bears 
in Jeffrey pine versus whitebark pine forests. First, red squirrels in the whitebark pine forests cut unopened cones from trees and cache them in moist accumulations of cone debris (middens) to prevent cones from opening. Bears excavate middens to pilfer cones and consume the seeds. Exploitation of middens by bears depletes food stores of squirrels (Kendall 1983, Mattson and Reinhart 1997). In areas where squirrels form middens, climbing trees to harvest cones might be more energetically expensive for bears than raiding middens. In contrast, on the drier east slope of the Sierra Nevada, Douglas's squirrels do not construct middens, and they cut relatively few cones of Jeffrey pines (Kuhn personal observation). When Douglas's squirrels harvest these cones, they store them individually in small holes in the soil. Consequently, there are no rich larders of cones for bears to exploit in this part of their geographic range.

A 2nd factor that might influence the foraging strategies of black bears is cone morphology. Seeds of whitebark pines are protected within relatively small, indehiscent cones $(\sim 50-70 \mathrm{~mm}$ long) with scales that are poorly lignified (Lanner 1982). Because cones are indehiscent, seeds are retained in cones until harvested. Most cones are cut and quickly stored by red squirrels, or dismantled by nutcrackers as they harvest seeds (Tomback 1978, Hutchins and Lanner 1982, Arno and Hoff 1989). Brown bears easily obtain seeds from whitebark pine cones by breaking them open with their teeth or by stepping on them (Kendall 1983). In contrast, cones of Jeffrey pines are larger $(\sim 137 \pm 16 \mathrm{~mm}$ long; Johnson et al. 2003), highly lignified, and armed with spines. Before scales open, seeds are difficult to extract and they remain unavailable to many species that forage for seeds. After scales dehisce, winged seeds fall from cones and are scattered by the wind (Krugman and Jenkinson 1974). Therefore, to obtain large numbers of these seeds, bears must harvest them from cones before the cones open. Thus, scarcity of easily pilfered squirrel middens in the region, and the difficulty of obtaining large numbers of seeds after they are wind-dispersed are likely the reasons why bears climb Jeffrey pines to harvest cones.

Black bears directly reduce future cone production of Jeffrey pine through seed predation and damage to trees. Cone-bearing branches were broken off at or near the cones, which are at the terminal ends of branches. Loss of terminal ends removes the apical meristem and cone primordia, thus reducing future growth and cone production. Meristem damage can have substantial long-term consequences for seed production (Strauss and Agrawal 1999). In addition to tree damage, black bears might reduce fitness of Jeffrey pines through predispersal seed predation. Unmasticated pine seeds were rare in scat samples, and those present were tightly bound inside the dense matrix of the scat. This suggests that in the unlikely event that seeds survive bear mastication and digestion, seeds might be unable to germinate unless freed from feces through weathering or foraging activity of rodents (e.g., Janzen 1982).

\section{ACKNOWLEDGMENTS}

We are grateful to E. Hager for her assistance in the field. S. Agosta, J. Briggs, M. Beck, W. Hampton, and E. Peacock provided useful comments on earlier drafts of this manuscript.

\section{Literature Cited}

ARnO, S.F., AND R.J. Hoff. 1989. Silvics of whitebark pine (Pinus albicaulis). USDA Forest Service, General Technical Report INT-253, Ogden, UT.

Beckmann, J.P., AND J. Berger. 2003a. Rapid ecological and behavioural changes in carnivores: the responses of black bears (Ursus americanus) to altered food. Journal of Zoology 261:207-212.

. 2003b. Using black bears to test ideal-free distribution models experimentally. Journal of Mammalogy 84:594-606.

Craighead, J.J., J.S. Sumner, and J.A. Mitchell. 1995. The grizzly bears of Yellowstone. Island Press, Washington, DC.

ForCELLA, F. 1981. Cone production by pinyon cone beetle (Conopthorus edulis; Scolytidae): dependence on frequency and magnitude of cone production. American Naturalist 116:594-598.

Goodrich, J.M. 1990. Ecology, conservation, and management of two western Great Basin black bear populations. Master's thesis, University of Nevada, Reno.

Hutchins, H.E., and R.M. Lanner. 1982. The central role of Clark's Nutcracker in the dispersal and establishment of whitebark pine. Oecologia 55:192-201.

JANZEN, D.H. 1982. Removal of seeds from horse dung by tropical rodents: influence of habitat and amount of dung. Ecology 63:1887-1900.

Johnson, M., S.B. VANDER WaLl, AND M. BorChert. 2003. A comparative analysis of seed and cone characteristics and seed dispersal strategies of three pines in the subsection Sabinianae. Plant Ecology 168:69-84.

KendaLl, K.C. 1983. Use of pine nuts by grizzly and black bears in the Yellowstone area. International 
Conference on Bear Research and Management 5:166-173.

Krugman, S.L., and J.L. Jenkinson. 1974. Pinus L. Pine. Pages 598-638 in C.S. Schopmeyer, editor, Seeds of woody plants in the United States. USDA Forest Service, Washington, DC.

LANNER, R.M. 1982. Adaptations of whitebark pine for seed dispersal by Clark's Nutcrackers. Canadian Journal of Forest Research 12:391-402.

Mattson, D.J., K.C. Kendall, and D.P. Reinhart. 2001. Whitebark pine, grizzly bears and red squirrels Pages 121-136 in D.F. Tomback, S.F. Arno, and R.E. Keane, editors, Whitebark pine communities: ecology and restoration. Island Press, Washington, DC.

Mattson, D.J., and D.P. Reinhart. 1997. Excavation of red squirrel middens by grizzly bears in the whitebark pine zone. Journal of Applied Ecology 34:926940.

McCutchen, H.E. 1996. Limber pine and bears. Great Basin Naturalist 56:90-92.

MEaLEY, S.P. 1975. The natural food habits of free ranging grizzly bears in Yellowstone National Park, 19731974. Doctoral dissertation, Montana State University, Bozeman.

Pelton, M.R. 2003. Black bear. Pages 547-555 in G.A Feldhamer, B.C. Thompson, and J.A. Chapman, editors, Wild mammals of North America: biology, management and conservation. 2nd edition. John Hopkins University Press, Baltimore, MD.
Roтн, H.U. 1980. Defecation rates of captive brown bears. International Conference on Bear Research and Management 4:249-253.

Schaller, G.B., T. Quito, and K.G. Johnson. 1989. The feeding ecology of giant pandas and Asiatic black bears in Tangjiahe Reserve, China. Pages 212-241 in J.L. Gittleman, editor, Carnivore behavior, ecology and evolution. Volume 1. Cornell University Press, Ithaca, NY.

Strauss, S.Y., and A.A. Agrawal. 1999. The ecology and evolution of plant tolerance to herbivory. Trends in Ecology and Evolution 14:179-185.

Tisch, E.L. 1961. Seasonal food habits of the black bear in the Whitefish Range of northwestern Montana. Doctoral dissertation, Montana State University, Missoula.

Tомваск, D.F. 1978. Foraging strategies of Clark's Nutcracker. Living Bird 16:123-161.

Vander Wall, S.B. 1994. Removal of wind-dispersed pine seeds by ground-foraging vertebrates. Okios 69:125-132.

1995. The effects of seed value on the caching behavior of yellow pine chipmunks. Oikos 74:533-537.

Received 17 August 2006 Accepted 18 January 2007 